\title{
A mobile mass on the tricuspid valve in a young female: The critical distinction between the vegetation and cardiac tumor
}

\author{
Yavuzer Kozaa, Uğur Kayab, Enise Armağan Kozac \\ a Ataturk University Faculty of Medicine, Department of Cardiology, Erzurum 25100, Turkey \\ ${ }^{b}$ Cardiovascular Surgery, Erzurum 25100, Turkey \\ ' Erzurum Regional Training and Research Hospital, Department of Anesthesiology, Erzurum, Turkey
}

\section{ARTICLE INFO}

Article history:

Received: 15. 5. 2018

Accepted: 27. 5. 2018

Available online: 15. 6. 2018

Klíčová slova:

Nádor srdce

Papilární fibroelastom

Trojcípá chlopeň

Keywords:

Cardiac tumor

Papillary fibroelastoma

Tricuspid valve

\section{SOUHRN}

Papilární fibroelastomy (PFE) jsou benigní nádory srdce s vysokým embolizačním potenciálem, které obvykle vycházejí ze srdečních chlopní. Popisujeme případ 34leté ženy s progredující dyspnoe a únavou. Transthorakální echokardiografie prokázala stopkatý, homogenní echo-denzní a vysoce mobilní útvar přirostlý k trojcípé chlopni. Vzhledem k velikosti útvaru a jeho mobilitě byla u pacientky stanovena diagnóza srdečního PFE a u pacientky byla následně indikována jeho resekce.

(c) 2019, ČKS.

\section{ABSTRACT}

Papillary fibroelastomas (PFEs) are benign cardiac tumors with high embolic tendency, and usually originate from the cardiac valve. We report the case of a 34-year-old woman who experienced progressive dyspnea and fatigue. Transthoracic echocardiography revealed a pediculated, homogenous echo-dense, and highly mobile mass attached to the tricuspid valve. The patient was diagnosed with cardiac PFE because of its size and mobility, and surgical resection was scheduled.
Papillary fibroelastoma (PFE) is a rare primary benign tumor that usually involves left-sided heart valves. They are the third most common cardiac tumors after myxomas and lipomas and account for less than $10 \%$ of all primary cardiac tumors. An accurate diagnosis and distinction from other intracardiac masses is essential because they are a potential cause of systemic emboli, stroke, myocardial infarction and sudden death. ${ }^{1,2}$ We report a case of a woman presenting with a history considering infective endocarditis, who was found to have PFE arising from the tricuspid valve.

A 34-year-old woman presented with complaints of progressive dyspnea and fatigue. Her past medical history was unremarkable except for an intrauterine device extraction two months ago. On admission, a physical examination did not reveal any significant abnormalities. Electrocardiography revealed normal sinus rhythm and all laboratory blood panels were unremarkable. An echocardiogram revealed a pediculated, $1.6 \mathrm{~cm} \times 1.7 \mathrm{~cm}$, homogenous echo-dense, and mobile mass attached to the atrial side of the anterior leaflet of the tricuspid valve. The valve was competent. She was afebrile and had no signs of infective endocarditis. Based on its characteristic appearance and echogenicity, pedunculated nature, and mobility, the mass was identified as a papillary fibroelastoma (PFE) (Fig. 1A, video 1). Magnetic resonance imaging (MRI) was performed for further tissue characterization. The mass appeared homogeneously hypo-intense on T2 weighted imaging. Delayed enhancement images after administration of gadolinium demonstrated signal hyperintensity caused by the fibroelastic nature of the mass (Fig. 1B). Based upon clinical symptoms and echocardiographic findings, the patient underwent surgical excision of the tumor. On cardiopulmonary bypass, right atriotomy revealed a friable pink granular mass at the anterior leaflet of the tricuspid valve (Fig. 2A). No thrombus or vegetation was noted in the right atrium. The mass was carefully excised on beating heart (Fig. 2B). However, there was significant tricuspid regurgitation after mass excision and following excision of the tricuspid leaflets and chordae, tricuspid valve replacement was performed with a $33 \mathrm{~mm}$ bioprosthetic valve (Sorin). Histology confirmed the definite diagnosis of a PFE (Fig. 3). The post- 


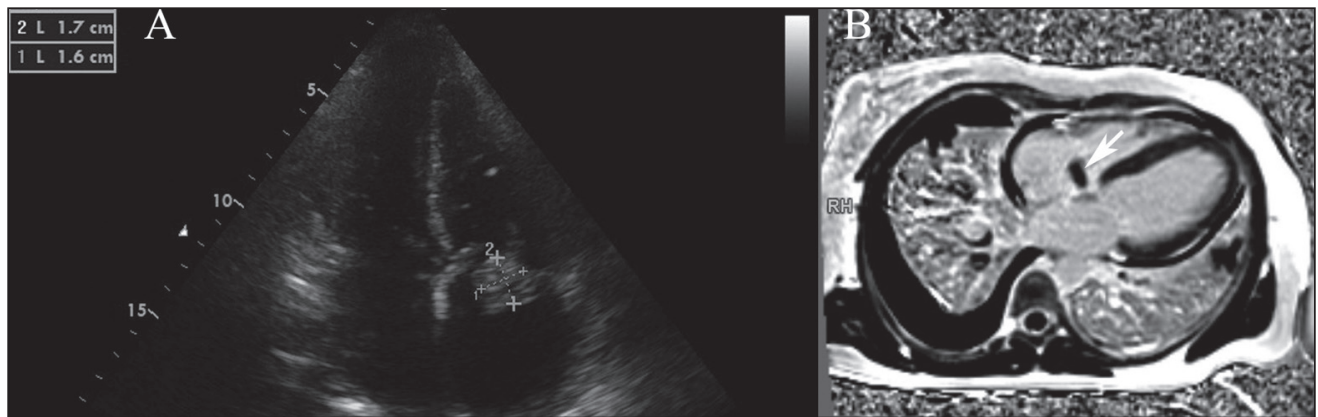

Fig. 1 - Transthoracic echocardiography (A), apical 4-chamber view, showing the mass, PFE visualized by Turboflush MRI imaging sequence with hyperintense signal relative to the myocardium, but hypointensity relative to the blood pool (arrow) (B).
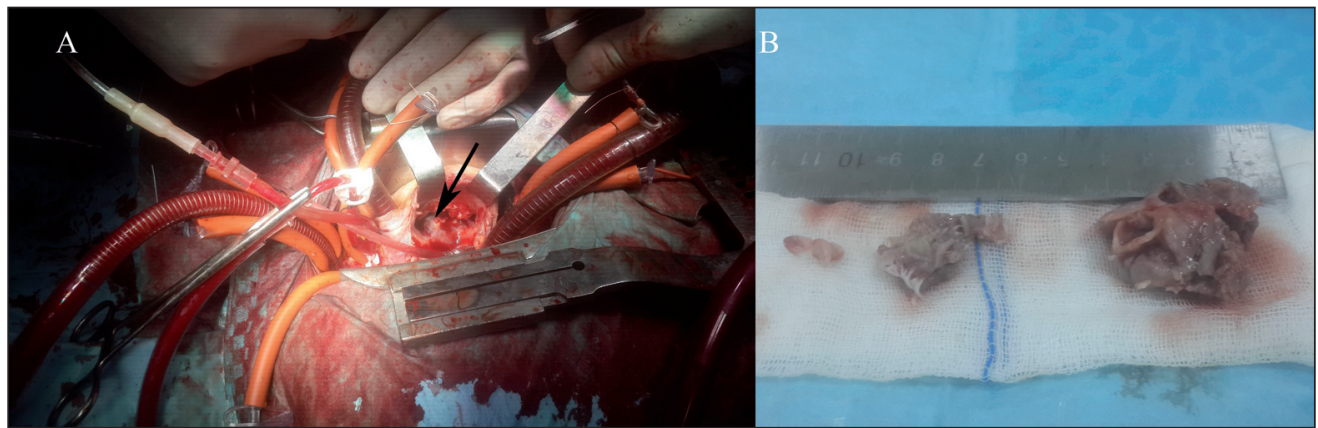

Fig. 2 - Intraoperative image (arrow) (A) and gross specimen of resected mass (B).

operative course was uneventful and after 3 months of follow-up, she remains free of symptoms.

PFEs are rare benign avascular cardiac tumors that typically attached to the left-sided valve leaflets with the aortic valve being the most common site. Tricuspid and pulmonary valve involvement is unusual. They are usually located on the ventricular side of the atrioventricular valves and the arterial side of the semilunar valves. PFEs are not causally associated with valve dysfunction. ${ }^{1,2}$

Although the ethiopathogenesis of PFE is unknown, various possible causes have been suggested in the literature. They have been considered as hamartomas, organized thrombi, true neoplasms or inflammatory foci due to unusual endocardial responses to infection or hemodynamic trauma. ${ }^{3}$

The clinical presentation of PFE varies widely from asymptomatic to severe embolic complications. Right-

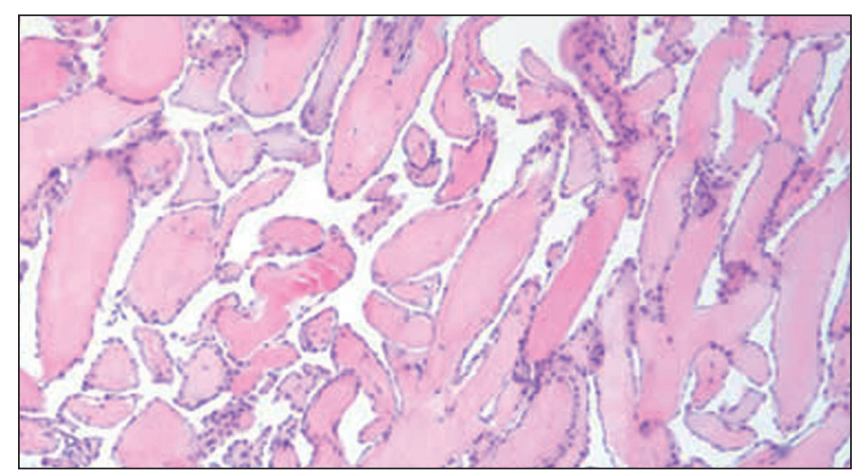

Fig. 3 - Histological specimen illustrating complex branching papillary fronds characteristic of PFE. -sided PFE are asymptomatic and rarely cause pulmonary embolism. The differential diagnosis of PFE includes other cardiac tumors, thrombus, vegetation, and Lambl's excrescences. One of the most considered differential diagnosis is cardiac myxoma. ${ }^{1}$ In the present case, the differential diagnosis included cardiac tumor and vegetation. Infective endocarditis was excluded based on the absence of fever, signs of valvular dysfunction, and a history of intravenous drug abuse. Blood cultures were also negative for microorganisms.

The echocardiographic characteristics of PFE include small size (usually $<1.5 \mathrm{~cm}$ ), high mobility, attachment to the endocardium through a pedicel or stalk, and refractive appearance. The distinction from the vegetations can be challenging due to their small sizes. ${ }^{4}$ Moreover, PFE may lack some of these findings whereas vegetations may represent many of these characteristics. For that reason, PFE can often be differentiated by clinical informations, blood cultures and laboratory tests. In this case, there was a history of infected intrauterine device extraction, so the clinical information was quite misleading. However, on $\mathrm{MRI}$, in contrast to vegetations, PFEs usually have complete enhancement in late gadolinium enhancement as seen in this case. PFE MRI features include isointense T1-imaging and hyperintense T2-imaging. ${ }^{1-4}$

The management of PFE depends upon its clinical presentation. Patients who are experiencing embolic events that are cardiovascular or neurologic in origin should undergo surgical resection. Although there are no firm guidelines on how to manage right-sided PFEs, surgery is shown to be curative, safe and well tolerated. ${ }^{4}$

This report not only highlights atypical presentation of this tumor but also reminds us to keep this possibility in 
patients who present with a history and imaging findings considering infective endocarditis. In patients with a high clinical suspicion for a cardiac tumor, advanced imaging tools such as MRI and computed tomography should be also used.

\section{Appendix A. Supplementary data}

Supplementary data associated with this article can be found, in the online version.

\section{References}

1. Palaskas N, Thompson K, Gladish G, et al. Evaluation and Management of Cardiac Tumors. Curr Treat Options Cardiovasc Med 2018;20:29.

2. Ruisanchez C, Alonso A, Carballo B, et al. Incidental tricuspid valve fibroelastoma associated with patent foramen ovale in a young female: Straightforward diagnosis but controversial management. Echocardiography 2017;34:1399-1400.

3. Bicer M, Cikirikcioglu M, Pektok E, et al. Papillary fibroelastoma of the left atrial wall: a case report. J Cardiothorac Surg 2009:4:28.

4. Klarich KW, Enriquez-Sarano M, Gura GM, et al. Papillary fibroelastoma: echocardiographic characteristics for diagnosis and pathologic correlation. J Am Coll Cardiol 1997;30:784-790. 